\title{
The hermit character as a new type of character in realistic prose by Maxim Gorky
}

\section{El personaje ermitaño como un nuevo tipo de personaje en la prosa realista de Maxim Gorky}

\author{
Strokina Svetlana \\ Sevastopol State University,Sevastopol, Russian Federation \\ ORCID ID: https://orcid.org/0000-0003-0311-0400

\section{Taymazova Lenie}

State Buget Educational Institution of Higher Education of the Republic of Crimea Crimean Engineering and Pedagogical University named after Fevzi, Yakubov Simferopol, Russia

ORCID ID: https://orcid.org/0000-0002-3034-6040

\section{Useinova Elvina}

State Buget Educational Institution of Higher Education of the Republic of Crimea Crimean Engineering and Pedagogical University named after Fevzi, Yakubov Simferopol, Russia ORCID ID: https://orcid.org/0000-0001-6147-5091

\section{Adonin Ruslan}

Sevastopol State University,Sevastopol, Russian Federation ORCID ID: https://orcid.org/ 0000-0001-9661-9403

Received 07-07-20 Revised 09-25-20 Accepted 01-13-21 On line 01-25-21

*Correspondencia

Email: StrokinaSvetlana@gmail.com
Citar como:

Strokina, S., Taymazova, L., Useinova, E., \& Adonin, R. (2021). The hermit character as a new type of character in realistic prose by Maxim Gorky. Propósitos y Representaciones, 9 (SPE2), e944. Doi: http://dx.doi.org/10.20511/pyr2021.v9nSPE2.944 


\section{Summary}

1922-1924 was a fruitful period of Maxim Gorky's literature work. It is related to searching a new art form. The cycle "Stories of 1922-1924" is an expressive example of "new prose". For the first time, the hermit character appeared in the cycle "Stories of 1922-1924". From the point of view of generally recognized morality and the Church, the new type of character is ambiguous. It is characterized by both sinfulness and holiness.

Keywords: Cycle "Stories of 1922-1924", new type of character, new prose, Maxim Gorky, hermit

\section{Resumen}

El tiempo desde 1922 hasta 1924 es un período fructífero de la obra de Maxim Gorky. Se trata de encontrar una nueva forma de arte. El ciclo "Cuentos de 1922-1924" es un claro ejemplo de "nueva prosa". El personaje ermitaño apareció por primera vez en el ciclo "Cuentos de 19221924". El nuevo tipo de personaje es ambiguo en términos de moralidad y religión universalmente reconocidas. Se caracteriza por la pecaminosidad y la santidad.

Palabras clave: Ciclo "Historias de 1922-1924", nuevo tipo de personaje, nueva prosa, Maxim Gorky, ermitaño

\section{Introducción}

Work of the famous Soviet writer Maxim Gorky has long been perceived in the context of Socialist ideology. With this one-sided approach, his works of the 1920s escaped the researchers' attention. Nevertheless, research of the artistic uniqueness of the cycle "Stories of 1922-1924" can serve as the basis for analyzing the writer's artistic uniqueness and socio-cultural processes of his time that took place in the post-revolutionary period.

Interest in the work of M. Gorky is associated with the attempts to rethink the whole creative heritage of the writer, and also with the analysis of a new character type.

\section{History of the issue}

The cycle "Stories of 1922-1924" by Maxim Gorky, despite the author's popularity, did not arouse interest among Soviet writers and critics, as well as among Russian emigrants. The lack of proper attention to stories is due to the difficult comprehension of their ideological and aesthetic component and, also, to the difficult socio-political situation in the country in the mid-1920s and 1924.

The rare works devoted to the analysis of Maxim Gorky's stories were mostly negative. Thus, V.G. Veshnev, describing the character of "The Hermit" story, said that the writer chose "the vilest sample of the human race", and called Gorky "the freaks' poet" (V.G. Veshnev). Completely different evaluation of the cycle "Stories of 1922-1924" is provided by N.N. Berberova, who personally knew the writer: "this entire period (the 1920s) undoubtedly contains the issues that will still exist when his early and later writings die. Why were these years like this for him? The answer is easy: because Gorky lived in the West and was free from Russian political situation, he didn't experience any pressure, being on his own. For some time, the writer was left alone, with a pen in his hand and a wide open mind" (Berberova 1999, p. 226). Nevertheless, critics paid attention at the fact that Gorky managed to create "exceptional 
phenomena of a national character" (K.G. Locks). K.D. Muratova wrote that in the works by M. Gorky human life is complex and confusing, and human psyche is deformed (Muratova 1971, p. 246). Critics attributed the peculiarity of Gorky's stories to his perception of disunity between the "people's" origin and the "people's" nature.

Maxim Gorky's innovation was that Gorky does not come from the conflict or from the plot, but he comes from the character's personal features (Gazizova 1994, p. 101-103). A.A. Gazizova believes that after the October revolution, a new concept of a person is born in Gorky's work (Gazizova 1994, p. 101-103), and the author is interested in original people with a unique personal features (Moskvicheva 1997, p.191).

\section{Problem Discussion}

\section{"New prose by Maxim Gorky"}

"New prose" by M. Gorky is a unique trend in Russian literature of the post-revolutionary period. A striking example of "new prose" was the set of stories written by Maxim Gorky from summer of 1922 to May of 1924.

The revolutionary events resulted in the writer a spiritual drama, since his expectations did not correspond to real apocalyptic revolutionary events. In autumn of 1921 Maxim Gorky goes abroad for treatment and fundraising for the benefit of starving people. Nevertheless, even there he experienced a difficult time, since he was not a friend of either the Bolsheviks or the Russian emigration. "The dreams, ideals, and utopia tried to come true, but at the same time they became distorted or directly opposite to all expectations and forecasts" (Leiderman 2008). This explains the reason for the split self-consciousness of Gorky's characters.

Gorky's spiritual drama, rapprochement with the "Serapion Brothers" literary group, and fascination with the poetry by V. Khodasevich lead to the writer's search for a new artistic form.

According to N.A. Bogomolov, in stories of 1922-1924 Gorky changed his manner of narration. His works acquire the features of psychological analysis. "Gorky's profound analysis of the character's spiritual world was determined not only by his own intentions (which contributed to the creation of perhaps the most valuable masterpieces in his life) but also based on the experience of other prosaic writers and poets, including Khodasevich" (Bogomolov 2000, p. 118).

In his cycle of stories, Gorky acts as an innovator. The researcher of his works O.V. Defier wrote: "in his new stories there is an artist whose main value is the independence of his own imagination, "street children of his fantasy". For the first time, he admits independence of the image from the author's will. In his new art, Gorky demonstrates a philosophical profoundness of life comprehension that is impossible, even unnatural for pragmatic "artists from the previous works about art" (Defier 1996, p. 103).

According to B. Mikhailovsky and E. Tager, a peculiar feature of Maxim Gorky's "new prose" is that the realism there has a hidden semantic subtext (Mikhailovsky \& Tager 1969, 210). The novelty of his prose is not related to the use of fancy words, but to semantic content of the narrative.

There is no desire for a better future in the new prose. Maxim Gorky wrote: "Life is becoming more and more interesting, more difficult, and I am for difficulty and against all sorts of "simplification", even if they would promise happiness to all my neighbors. Anxiety is richer than peace. Life is becoming more and more virtuosic, and the man is like a cello: it does not play without the touch of a musician's bow" (Byalik 1956, p. 136). The system of characters created by the author has a special psychologism. While describing the cycle of stories, B.A. Byalik spoke of their "profound psychological analysis" (Byalik 1956, p. 18-19). A.K. Voronsky saw the reason for this in the "incompleteness" of the writer's talent (Voronsky 1987, p. 39). According To V.K. Pankov, Gorky managed to disclose the social evolution of mentally confused people (Pankov 1968, p.138).

An innovation of Gorky's prose was the image of the character's disorientation and disintegration (Semenova 2001, p. 43). 
The mischievous character, the seeker of truth and justice, the eccentric character, the restless, unsatisfied person, the restless wanderer, etc. already existed in Gorky's literature before. However, in his earlier prose, the whole galaxy of such characters was penetrated with the fervent and fresh youth romanticism. In the stories of 1922-1924, the author's attention is drawn to a new character, and something new has been discovered in his image. A.K. Voronsky notes that Gorky's "mischievous" stories, novels and memoirs are characterized by curiosity and interest in life. They have something from the sly look of Luka and, at the same time, they are characterized by a calm observation, a freedom from preaching, a certain degree of completeness and thoughtfulness in their "mischievous" worldview" (Voronsky 1987, p.39). If the romantic worldview is typical for works covered with romanticism, then, in the stories of $1922-1924$, social romanticism is replaced by a gloomy realism. The author's ideological shift is evidenced by the fact that a decade earlier (in 1911) Gorky reproached L. Andreev for using gloomy pessimistic tones in his work "Darkness": "There was a feast, there was a victory of man over the beast, but you played anarchism and made the beast and the flesh triumph over the human being. We all will die, but the world will live; the world showed me and imposed on me a lot of evil and dirty things, but I do not want and do not admit his abominations, I have nothing to take revenge on the world, there is no need to poison people with a shameful look of my wounds and ulcers" (Semenova 2001, p. 90).

\section{"The Hermit" story in the system of the cycle "Stories of 1922-1924"}

Special attention must be drawn to "The Hermit" story, a part of the cycle "Stories of 19221924". The cycle of stories is preceded by "The Hermit" story. According to V.A. Slavina, in "The Hermit" there is no ideology from the previous works by Gorky. However, in them, the author looks at the character from the perspective of his contemporary (Klimov 1988, p. 18). The story does not contain any satire, denunciation or pathos, the author does not bear the narrator's function. However, there are characters who reveal themselves "from the inside". The story doesn't have a plot or a cause-and-effect events' development.

In the genre aspect, "The Hermit" story tends to be an essay. Maxim Gorky became interested in this genre at the end of 1910s. According to M.N. Klimova, the essay is a small epic genre form of fiction associated with realistic traits, which contains a detailed and complete narrative of the event (Klimova 2000, 40). In this genre, the plot is usually bright, documentary and truthful. Also, B.A. Byalik depicts the novelistic nature of M. Gorky's stories written in 1920s (Byalik 1956, p. 18-19).

The characters of this cycle of stories by Gorky are ordinary people who live in a critical period and, by fate, experience the problem of re-estimating their values. Through real life situations, a philosophically rich subtext is perceived. In "The Hermit" story, there is the key motif of reclusion (life in solitude) and asceticism. Alienation is associated with an inner need for solitude. Alienation from society is associated with internal dissent and protest.

The main motives of Gorky's stories are:

1) non-humiliation of the man by means of pity;

2) motive of the game, related to the description of nature and amazing speeches of the main character. In the stories' cycle, according to the researcher N.L. Leiderman, the game "becomes the engine of psychological plot" (Leiderman 2008);

3) "motive of "dust", reflecting all the dead and stagnant phenomena typical for life, and art" (Pshenichnyuk 1987, p. 12;

4) motive of the extraordinary. Gorky often uses synonyms for the words "extraordinary" (unusual, unusualness ("The Story of Unrequited Love", "Caramora", "Anecdote"), impossible ("The Hermit"), strange, special, amazing ("The Story of Unrequited Love") (Bereznyatskaya 2017, p. 28).

The characters of Maxim Gorky have an unusual appearance. They early leave this world. For example, "Strange Olesha", a character of the cycle "Stories of 1922-1924", comes to Savel for comfort. "Olesha regards himself as a man with an evil heart, as a violent man, who suffered from failures. Nevertheless, Savel Pilschik calmly replied to his words: Your heart is an ordinary human anxious heart - it does not like anxiety, but it asks for some peace..." (Gorky 1973, 252). 
Olesha agreed with Savel Pilschik and his "sullen", "robber's" face turned "into a stupid goodnatured face of an ordinary home animal" (Gorky 1973, p. 251). From 1922 to 1924. Maxim Gorky creates a fundamentally new psychological type of character. His characters are not at the stage of spiritual development, they are more characterized by a sense of spiritual loss associated with the deformation of their attitudes to the social structure. Many of his stories have a dark, pessimistic tone. His characters are losers, traitors, mentally ill people, etc. They are placed in borderline situations, "as if the writer undertook to test the person's limits, the limits of his irrational self-will, his perverted revolt against the very death-natural conditions of human existence, against his criminal impulses..." (Gorky 1973, 28). The revolution provoked a crisis in people's worldview. Traditional way of life was breaking down.

After the revolution, a person experiences some pressure, accompanied by destruction of values and norms. Thus, the character becomes a hermit and goes to the monastery. The author's narrative is centered on the personality. According to Gorky's tradition, there are two different poles of people. On the one hand, it is a Person with a capital letter ("Mother"), and on the other, it is a minor person ("The Life of an Unnecessary Man").

The man is a mixture of low and high, which does not allow to esteem him unambiguously. Characters of the story are losing control of their fate. The characters' fates depend on other people. Significant changes arise in the character's life, there is a need to evaluate everything. The story is penetrated with a sense of tragedy, a fatal predisposition to human fate.

The characters radically differ from previously created ones.

\section{The hermit character as a new type of M. Gorky's character}

During the rapid construction of a new state, Maxim Gorky refers to archaic image of the hermit. "The Hermit" story is the first story in the cycle "Stories of $1922-1924$ ". This story opens a new trend in the image of the hermit character. The main character of the story is Savel Pilschik. "The Hermit" story is devoted to his biography. The main character is depicted with a special realistic psychology, with a special realism. Savel Pilschik has an ugly appearance. "An old man of medium height, stout, but he looks as if he was crumpled or bitten. His ugly face is red like a brick, his left cheek from ear to chin is cut down by a deep scar, he twitched his mouth, bearing the painful-mocking expression, his dark eyes without eyelashes are damaged with trachoma, he has two red scars instead of eyelids, the hair came out in patches, a small patch on the top and a patch near the left ear" (Gorky 1973, p. 246). The character's appearance corresponds to his analytic character: "scattered inner world", "rare bristles of eyebrows", "gray, frayed and plucked mustache". However, the "ugliness of a disfigured face" is brightened up by Savel's eyes; his eyes are "torn", "vivid", "heerful", "naked", "without eyelashes". Landscape background plays an important role in the story. On the one hand, it provides a realistic and documentary description of the character's appearance. On the other side, landscape helps to reveal the character's inner world. "The forest ravine sloped smoothly down to the yellow Oka, a stream ran along the bottom, hiding in the grasses; sky, like a blue river, floated over the ravine, invisible during the day and trembling at night; the stars were playing there like golden ruffs.

At the South-Eastern shore of the ravine, thick and tangled shrub was growing, in the very thickness of it, under a steep slope, a cave is dug. It is covered by the door, skillfully made of thick boughs. In front of the door a reinforced cobblestone platform is poured in a seven feet square. From there, heavy stones are descending to the stream like a ladder. Three young trees grow in front of the cave door-linden, birch and maple" (Gorky 1973, p. 236). However, lyrical digressions and depictions of nature from "The Hermit" story are not typical of other stories from this cycle.

The story lacks the author's evaluation of the character and his actions. Dialectic personality of the character makes him a pragmatic person. The character of Savel Pilschik is ambiguous, thus it is extremely difficult to evaluate him.

The character compares his own life to the bird's flight. Savel speaks of himself: "I lived like a Turman", you know - "Turman is a kind of dove" (Gorky 1973, p. 236). 
His success is alternated with decline ("it flies high to the sky" and "plops down"). Gorky raises the topic of sinfulness and holiness. Implicitly, the story reflects the religious and ethical motive of sinners.

Savel Pilschik is both a saint and a sinner. He appears before the reader in the image of "the holy fool". After the death of his wife, he was accused of incestuous relations with his daughter, but he did not see anything reprehensible in this fact. According to ethical and religious norms, Savel is a sinner who molested his own daughter. The author does not forget about this. "Every person is not bad during all his life, sometimes even a bad man is worthy of praise. A person is not a stone, but even a stone can change as the time goes" (Gorky 1952, p. 8). The character does not recognize or deny this fact. "The Hermit" contains the character's story about a saint who married his daughters, and they gave birth to the prophets Abraham and Isaac. However, there is a contradiction to the Bible. In the Bible, the daughters of Saint Loa had children from their father due to the lack of men. It is doubtful that Savel Pilschik did not know the Bible. The author deliberately makes a mistake, since true faith and morality do not consist in accurate knowledge of the text, but they consist in life principles. The narrator's attitude to the author is expressed in the words: "Is this a saint with a treasure of immeasurable love for the world?" (Gorky 1952, p. 21). Describing his daughter, S. Pilschik says: "an impossible beauty". He admires her beauty. "I see that Tasha also came in mittens and boots, a real beauty!" (Gorky 1973, p. 236).

The fact of incest raises doubts about the sanctity of Savel Pilschik. Savel Pilschik is judged, he is wandering in search of God. However, the story does not mention any remorse. "The character's words are full of resentment and sadness. It's all for nothing, just for show, they are trying to show that they are guarding the laws! But it's a deception. All laws, orders and papers have no sense. Let everybody live on their own" (Gorky, 1973, p. 236).

Gorky pays special attention to love topic. A contradictory image is disclosed by "a boundless, inexhaustible love - a selfish and self-admiring love, love that regards itself as the meaning and purpose of being, love that has accumulated all the beauty of life, love that is enveloping the whole world with its power. At that time, I was already well able to disbelieve, but during this cloudy day all my disbelief disappeared like a shadow before the sun, at these sounds of a familiar word, worn out by the tongues of millions of people" (Gorky 1952, p. 14). Love in character's life has a defining meaning. Thanks to love, the hero is rising up and falling down. By the standards of society, his love is wrong; thus, the character is condemned. But, at the same time, this love helps Savel Pilschik to find a new sense in the life. In the sin - repentance salvation triad, Savel takes care of other people. Being in seclusion, Savel Pilschik helps people. People who want help are drawn to him. They go to the hermit in order to calm down, to find hope, etc. "If you were offended, the God was also offended". God is in your soul, His Holy spirit lives behind your breast, and your brothers are fools, they hurt Him with their stupidity, they should be pitied because they did badly" (Gorky 1952, p. 20). Love is related to the character's ability to fill trivial words with meaning. The character pronounces the word "dear" in a variety of ways "with emotion, with triumph, with some touching sadness, with reproach and affection, pouring out a shining sound of joy" (Gorky 1952, p. 24). In "The Hermit", one can see lovesympathy, sacrificial love, and love-salvation. Each of these hypostases serves to reveal a complex multidimensional image of the hermit.

The hermit's house is a place where people are drawn, seeking advice and consolation. All of them find some comfort there. Hermitage is a religious way of life associated with the restriction of one's communication. Nevertheless, Savel Pilschik is not committed to privacy. He is frank and open to people, always willing to help them. Savel is charming, he is characterized by a peaceful love of life. Suffering people are drawn to him because they hope to find the answers at questions that are tormenting them. In the image of hermit, one can trace the author's features. A.V. Lunacharsky recalls: "Gorky lives in Sorrento, and you have to go in a faraway land in order to visit this red house, where the great writer lives as a hermit. He seems to be a hermit. But what kind of hermit am I speaking about? The doors and windows of Gorky house in Sorrento are always opened on all the four sides" (Lunacharsky 1964, p. 564). However, the character does not completely break with the world. "The monks call me to take the veil, to become an elder. It is profitable for them, it is an attraction for people, but I don't want to, I'm an ordinary man, it's not good for me. Am I saint? No, I am just a friend and a quiet man" (Gorky 1952, p. 13). 
Thus, the motive of hermitage in Maxim Gorky's work differs from the traditional understanding.

K.D. Muratova noted: "Usually images of hermits are associated with ideas about of guides or ascetics. Gorky's character is not like them. The traits of righteousness and sinfulness are closely merged in him; he is one of the "contradictory "people" (Muratova 1958, 24). In the character of Maxim Gorky, we see a longing for love to people.

Analyticity and possession of folk wisdom contribute to the fact that the hermit becomes attractive for people.

A special place in Gorky's concept sphere of this time period is occupied by the hermit character. Gorky creates absolutely new image of the character. It is a hermit, who is capable of philosophical life comprehension.

A new type of character (the hermit) is characterized by psychologism. Landscape background plays a significant role in revealing the image of Savel Pilschik, giving realism to both the character and the events happening.

The main psychological features of the new hermit character are dialecticism, ambiguity, a combination of holiness and sinfulness, incomplete solitude.

\section{Conclusiones}

"New" prose of Maxim Gorky is opened with a cycle "Stories of 1922-1924". Its creation is associated with revolutionary events and the Civil war that followed. Realism of the narrative is recreated by referring to the essay genre. The writer's innovation is in the presence of a certain semantic subtext, enriching the gloomy realism of Maxim Gorky with a new sense. The constant of "new prose" is the lack of pity for the character. Special psychologism of Gorky, typical of the new prose, is associated with the game. The past goes into oblivion, but the characters keep on living, adapting to new conditions. The strange character is associated with the lack of opportunity to evaluate him from the position of accepted social norms and judgements. The characters of "new prose" are characterized by a special psychologism, they have an unusual appearance, they perform unusual actions, etc. The new character of M. Gorky is the synthesis of the high and the low. Thus, he loses control of his fate and goes to the monastery, becoming a hermit.

\section{Referencias}

Berberova, N.N. (1999) Kursiv moi: Avtobiografia [My italics: Autobiography]. Russia, Moscow, 734

Bereznyatskaya, M.A. (2017) The motive of "extraordinary" and its aesthetic function in "Stories of 1922 - 1924" by M. Gorky. Vestnik VGU [VGU Herald]. Series: Philology. Journalistics, Russia, 27-33

Bogomolov, N.N. (2000) Russkaya literature nach. XX veka I okkultizm [Russian literature of early 20-th century and occultism], Russia, Moscow, 549

Byalik, B.A. (1956) Tvorchestvo M. Gorkogo v sovetskuyu epokhu [Works of M. Gorky in the Soviet time], Russia, Moscow, 76

Defier, O.V. (1996) Proza M. Gorkogo o khudozhnike I iskusstve [The prose of M. Gorky about the art and the artist], Russia, Moscow, 103-110

Dzyuba, A.S. (2011) The trait of essay genre in "The Hermit" story by M. Gorky. Vestnik Universiteta Rossiiskoi akademii obrazovainya [Herald of the University of the Russian Education Academy]. Philology and Journalistics. № 1, pp. 36-39

Fisenko, O., Nikitina, \& V., Bodrova, T. (2019) Semantic-cognitive approach to the study of a language person in the system of human and individual values. Chile, Santiago, 106112

Gazizova, A.A. (1994) New Gorky (1920-es). A.M. Gorky i literaturny process XX veka [A.M. Gorky and literature process of the 20-th century]. Gorky Conference, 1994, Russia, Nizhny Novgorod, 101-103

Gorky and the Soviet Writers (1963) Unpublished correspondence. Literature legacy. Vol. 70. Russia, Moscow, 736 
Gorky and the Soviet Writers (1963). Unpublished correspondence. Literature legacy. Vol. 70. AN SSSR. Institute of the World Literature named after A.M. Gorky. Russia, Moscow, 736

Gorky, M. (1973) Complete collection of works. In 25 vols Vol. 17. Russia, Moscow, 540

Gorky, M. (2002) Complete collection of works. Letters in 24 vols, Vol. 9. Russia, Moscow, 825

Gorky, M. (1952) Complete collection of works in 30 vols. Vol. 16. Russia, Moscow, 13

Klimova, M.N. (2000) Reflection of the myth about the great sinner in the story of A.M. Gorky "The Hermit". Vestnik TGPU [The herald of TGPU]. Series "Humanity sciences (philology)". № 6, 39-42

Leiderman N.L. (2008) Unread Gorky. Ural [The Urals], № 7, Available at: http:// magazines.russ.ru/ural/2008/7/le13.html (Accessed 17 January 2011)

Locks, K.G. (1926) Old and new Gorky. Pechat' and Revolutsiya [Press and Revolution]. №3, 22-85

Moskvicheva, G.V. (1997) Works of M. Gorky in the first years after the October Revolution. Uchenye zapiski [Scientific notes], Issue 52. Russia, Gorky, 658

Muratova, K.D. (1971) M. Gorky v borbe za razvitie sovetskoi literatury [M. Gorky in the struggle for the development of the Soviet literature], Russia, Moscow - Leningrad, 485

Ovcharenko, A.I. (1971) Selected works. Gorky i literaturnye iskaniya XX veka [Gorky and literature searches of the 20-th century]. Vol. 1. Russia, Moscow, 286

Pankov, V.K. (1968) Gorky i sovetskaya deistvitelnost' [Gorky and the Soviet Reality], Russia, Moscow, 380

Pshenichnyuk, T.M. (1987) Sotsialnaya i estetichesksya priroda rasskazov M. Gorkogo 1922 - 1924 godov. Doct., Diss [Social and aesthetic nature of M. Gorky stories of 1922 1924. Doct., Diss]. Russia, Sverdlovsk, 19

Semenova, S. (2001) Russkaya poeziya i proza 1920 - 1930-kh godov [Russian poetry and prose of 1920-s - 1920-s]. Russia, Moscow, 592

Slavina, V.A. (2020) Russkaya literatura XX v. [Russian literature of the 20-th century]. Tutorial, Russia, Moscow, 333

Spiridonova, L.A. (2004) M. Gorky: Novy vzglyad [M. Gorky: new look]. Russia, Moscow, 190

Tager, E.B. (1964) Tvorchestvo Gorkogo sovetskoi epokhi [Works of Gorky of the Soviet time]. Russia, Moscow, 378

Trouaillard Henri (2004) Maksim Gorky [Maxim Gorky]. Russia, Moscow, 315

Veshnev, V.G. (1927) Bitter Sweet. Na literaturnom postu [At the literature post]. № 27, 47

Voronsky, A.K. (1987) Iskusstvo videt' mir [The art of seeing the world]. Russia, Moscow, 700 